\title{
Otherness: The Primary Cause of the Unrest Problem in the Three Southern Border Provinces of Thailand
}

\author{
Kettawa Boonprakarn ${ }^{1}$, Kasetchai Laeheem ${ }^{1} \&$ Jedsarid Sangkaphan ${ }^{2}$ \\ ${ }^{1}$ Faculty of Liberal Arts, Prince of Songkla University, Hat Yai, Songkhla, Thailand \\ ${ }^{2}$ Faculty of Liberal Arts and Education, Hatyai University, Hat Yai, Songkhla, Thailand \\ Correspondence: Kettawa Boonprakarn, Faculty of Liberal Arts, Prince of Songkla University, Hat Yai, 90110 \\ Songkhla, Thailand. E-mail: kettawa@hotmail.com
}

Received: November 28, 2014 Accepted: February 10, 2015 Online Published: May 15, 2015

doi:10.5539/ass.v11n15p61

URL: http://dx.doi.org/10.5539/ass.v11n15p61

The article is part of "Flowers amidst the blaze": Establishing otherness amidst rumors and constructing mechanisms for fighting and negotiating among teachers in the violent situation in Pattani Province.

\begin{abstract}
The purpose of this article is to review the concepts, theories, and research reports related to the concept of otherness, especially those mentioning other within and defining "otherness". The researchers analyzed and synthesized data collected from related literature reviews, and found the following definitions. 1) Otherness is an invention constructed by society under authority relationships to exclude and push away people who are different from the self to a lower social position, and nature is made into otherness by repressing and obstructing it to allow humans to be the master of nature. 2) Refused otherness is a result of conditions, identities, and positions given by society. Those who are pressed to accept these characteristics refuse ones that are not their own in order to separate "Them" from "Us". This may not refer to the construction of the opposite identities but rather of new identities instead. 3) Ethnic otherness is designated by the discourse of civilization as a result of an effort to construct a new type of state with boundaries to exclude others because of their races, ethnics or groups that are the same or different. 4) Construction of otherness in the three Southern border provinces of Thailand has emerged from the process of building a nation state, and the process of Thai-ization that takes place under the concept of exclusion and nationalism. This has resulted in culture of the majority of people in the country and that of the minority who are non-Thai with the status "Other within" of Thai society. In addition, the absence of understanding in cultural diversity has partially contributed to the unrest situation in the area.
\end{abstract}

Keywords: otherness, other within, construction of otherness

\section{Introduction}

The concept of otherness is based on a thought of separating things as contradictory pairs, especially distinguishing identity from differences, or distinguishing the "self" from the "other" (Charoensin-o-lan, 2002, 3-36). However, according to a study by Fueangfusakun (2003), the "self" can exist only when there is the "other". The study further describes that looking back at Western philosophers' thoughts, we find that Hegel thought that humans can realize about themselves only when they associate themselves with the outside world. Hegel gives an example about a master and a slave; the master separates himself from the slave because the master perceives that the slave is outside of his world, and therefore, the slave is not the master. According to the dialectical method, Hegel considers that human awareness is developed from antagonistic phase between the master and the slave to realization that the master can exist only when there is a slave to serve him, and the slave realizes that his life depends on his master. Thus, each party realizes that the existence of the other completes his own existence. The binary opposition concept emphasizes that we can exist only when there is the others support our existence. For example, we can have a higher position only when there are others below us; or we can classify people as normal only when we can define those as abnormal (Cuff, Sharrock, \& Francis, 1990, p. 253). In this sense, even others who are different from us can be identified as part of us to make us complete or clearer. Separating ourselves from others is, therefore, not an absolute separation. If we and the others are the two sides of the same coin, for example, being a Thai has a complete meaning only when we realize what is not Thai such as being a Myanmar, being a Malay, etc. In other words, we cannot define being Thai, if there are no others who are different from us. Similarly, in the three Southern border provinces of Thailand, most people are Muslims 
and call themselves "Orang Melayu" even though they live in Thailand, they identify themselves as Melayu. This identification constructs otherness for the other group of people called "Orang Siam", which is used to refer to Buddhists who are Siamese, and otherness is further emphasized that it causes suspicions between the two groups by using religion in a distorted way, describing ethical differences and exploiting violence resulting in an absence of trust between the two cultures. This has affected relationships between Thai Muslims and Thai Buddhists. Different cultures affect actions between them including insurgency that gives Thai Buddhists living in the three border provinces of Thailand a higher degree of otherness, especially, Buddhist teachers, monks, soldiers, and other government officials.

From the above phenomena, we found that creating a nation state has a side effect, that is exclusion of different ethnics making them "other within", and Thailand is no exception (Winichakul, 1987). The violence in the three Southern border provinces of Thailand originated from the operation of the construction of "Us", that is constructing Buddhist society a Thai state compared with "Them", which is Muslim society or Chinese society, and other minorities making them others or inferior. This thought is considered an accumulation of fuel of disrespect for differences awaiting the right time to burst out with violence. This is evidenced by the existing unrest situation in the three Southern border provinces of Thailand.

Thus, this study aims to find out how otherness is defined, and what refused otherness, and ethnic otherness are like, and what the characteristics of otherness in the three Southern border provinces of Thailand are. In this study, the researchers try to determine the answers by looking back at the state and functions of the state mechanisms because we cannot deny that presently the state controls, penetrates, separates Them from Us, and creates other within.

\section{Research Methods}

Concepts, theories, and research reports related to otherness conducted domestically and abroad were analyzed with emphases on 1) definitions of "otherness"; 2) refused otherness: separating them and us; 3) ethnic otherness; and 4) the construction of otherness in the three Southern border provinces of Thailand.

\section{Results of the Study}

\subsection{Definitions of "Otherness"}

Otherness is a concept referring to something that is not correct in a context in order to push that incorrect thing to a lower position than oneself. For example, during the period when racism was an issue, Africans were treated in such a way that reduced their value as humans in society because of their race.

Fabian (1991) describes otherness or "others" as non-existing; it does not wait to be found but it is constructed, or it is a story that is composed. This concept corresponds with Thai academics who specify that otherness is an invention invented by society under authority relationship to exclude and push people who are different from oneself to an inferior condition or social status in order to establish greatness, and to empower one's own group.

Otherness can be defined using two methods. The first one is the construction of otherness to people, and the other is the construction of otherness to nature. The first method can be seen from a study by Foucault on the relationship between power and other people under authority relationship using dialectical method. That is power cannot exist alone but power has to construct other people to protect its pure being. Therefore, while some people are accused as unreasonable, other people are considered reasonable (Huspek et al., 1977, pp. 95-116)

The other method is making nature into otherness. This is to expand and add delicacies to the construction of otherness so not to limit to analysis of only relationships among humans themselves. Making nature into otherness is a concept developed by critical feminist thinkers. In the study by Plumwood (1997), dualism, a mainstream thinking of Western culture separates humans from nature; humans are rational animals but this separation does not mean to cut off the relationship between them. Rather, this is to make animals objects to be used by humans while making humans powerful to occupy, manage, and change nature.

Plumwood considers that the important contradictory pair that leads nature to otherness is the distinguishing of reason and nature, where reasons are praised while nature is repressed and obstructed. Nevertheless, the goal of constructing otherness is not to repress and obstruct only nature but also other things that are not nature as well. These are diversified groups of people classified into the same category as nature. For example, females, people living in a colony, and lower class people (Charoensin-olan, 2002).

Plumwood (1997) indicates that the construction of otherness is an authoritative technique under the concept of contradictory pairs, and dominating nature is the same process as dominating humans, that is by repressing and obstructing them because of their sex, social class, and race. However, the construction of otherness is neither 
direct nor simple, but it consists of complex mechanisms to make the others dominated in terms of thinking, and considers otherness as a classification of levels between the superior and the inferior others. Therefore, the goal of the construction of otherness is not straightforward but it is an authoritative technique committed against others with tricks, complications, and shrewdness.

In conclusion, otherness refers to a process of emphasizing on differences with an aim to reduce values of others so that they are different or lower than us. Otherness is an authoritative technique used to establish or open a space for power to manage the "others" no matter whether the use of such power is negative or positive (such as killing or supporting). Nevertheless, otherness may not be committed directly against only humans but also natural environments by repressing and obstructing nature so that humans become the master of nature, which can be referred to as a process of making nature into otherness.

Kastoryano (2002) presents three methods of defining "otherness". The first one is communications referring to interactions between the state and groups seeking to be politically recognized through interactions that can measure the dynamics and mechanism in constructing boundaries and showing legal characteristics. The second one is regulations based on correctness according to legality and equality leading to recognition. The last one is politics based on empirical truth and understanding of rules and regulations leading to a change of institutions. These three methods shows how clear or how vague the identifications are, which are known as "permanent differences", a major source of separation in one society

\subsection{Refused Otherness: Separating "Them" from "Us"}

Hall (1996) refers to the self and otherness stating that individuals are like stitches on the wound; one side of the wound is the identity that the discourse affects the individuals, and the other is the process of interaction the individuals have towards the discourse. Individuals are the feeling, and the internal experience happening specifically according to the context at that moment without any core. New identities originate when the individuals interact with the discourse that affects the individuals, and they are not fixed but flexible according to the context, situation, or discourse that affects them. The process that is happening is called position shifts reflecting that defining identities happens by drawing lines to separate things from each other; refusing properties that do not belong to them such as good deeds are not bad deeds. Thus, the meaning of the identity can exist because it depends on the opposite meaning. Similarly, "otherness" that is refused is the opposite with conditions and needs for the existence of the identity. Identities that are unfixed are a negotiation process of the individuals, which can be done by questioning to refuse the position given by society; it is not direct resistance or construction of the opposite identity, but it is a new identity to replace the one given to them (Soontravaravit).

Bhabha in Wungeao, (2003), a post-colonial academic, specifies that "the otherness" is a result of the colonial period where colonial discourse usually places relationships of groups of people based on fixity of the ruler. "Otherness" is something untidy and always changes, and the stereotype in the form of knowledge. Making an effort to separate otherness with various discursive strategies was an effort to manage everything in the relationship, system in which the rulers uses discrimination power, called the "process of ambivalence" through hatred, and bias. Therefore, classification of the self of this group, which is repressed, is called "marginal" of society by constructing it through drawing pictures according to the discourse of colonial otherness.

For Simmel (1971, p. 144), alienation and otherness can happen to people near and far, and alienation that becomes an element of a group is no different from the poor and their inner enemy. The element that shows membership is found outside the group as well as those contacting and relating with those inside and outside the group. This depends on the codes, categories, and boundaries that indicate their coexistence, separation, adaptation, and abnormality caused by those outside the group. This is in accordance with Becker (1963) who mentions about not recognizing of being in the same group through the political norms or social and cultural codes. The construction of otherness needs to have symbolic boundaries (Lamont \& Fournier, 1992). Boundaries bring about internal differences in the construction of society, culture, and moral in which cultural hierarchies are constructed with complex relationships, and each element is a basis for study of the social boundaries of small society. According to Baudrillard and Guillaume (1994, p. 50), "otherness is crossing a boundary, and a boundary can be totally imaginary and invisible". Even though the territory boundaries are needed for designation of the unity of a state, they are related to nourishment of art and historical experiences of a nation that describes the route from the cultural framework to the political framework. This route is realized through institutional establishment with similarities and differences, an operation that is performed through identities in terms of language, race, and religion.

In addition, it was found that identity boundaries could be made from natural relationships or from formal institutionalization such as the census or they could be made from discourses, or political rights. These echoes 
are found in what Taylor (1992) referred to as political recognition in democratic defenses of societies with differences under expectations of educated society that is opposite to small political groups merging to form a large group. Although political recognition aims to reduce inequalities, creating frameworks that separates the group of sameness from the group of differences. Political recognition identifies the self of other groups and designates culture, society, economy, and law (Fraser, 1995; Caillé, 2004, p. 23).

Perception of otherness brings about designation of public rights and fundamental rights, boundaries that indicate equalities of people in society fundamentally and legally. Written legal rights reinforce broad perception and realization of specific groups that confirm differences with reference to social, cultural, and economic environments. These specifications are utilized as new characteristics of indicators that separate them from us.

\subsection{Ethnic Otherness}

A study by Simon (1999) indicates a change in the concept concerning the boundaries that separates otherness from using races as boundaries to ethnicities or groups of people who are the same or different or the existing diversity. This study also found that "race is a bounded and durable trait", and found that diversity is important in making it more difficult for America because of overlapping among groups that are classified making it more complicated to classify races for social equality policy. Huntington (2004) writes in his last book, "Who Are We?" that "language" is an important symbol that is a boundary between newcomers or Hispanics and those whose nationality is American, and criticized the fact about the target which is deemed as an exchange that is different under the same language. Thus, it is dangerous for Anglo-Saxon, and it was suggested that there should be adaptation to the American society. Even though his suggestion is not for the large group as a whole under studies about immigration and ethnics, definition of the ethnic difference was changed by adding to it a language (Spanish) and a religion (Catholic), which is an addition of differences in the race. Besides, Gans (1979) defined otherness or being the same group as having the same historical background rather than racial background. Identification of the boundaries for white groups is seen from differences in religion but the same origin, for example, "Jews in Eastern Europe and Irish Catholics".

The above definitions not only add the religious, and race issues to the classification but also historical and political backgrounds to make it clearer. In 1946, there was a related article concerning the Fifth Republic of 1958 that France could not be divided. Unity community, democracy, and socialist republic provide equalities to citizens before there were laws stating differences in origin, race and beliefs, which make these two definitions vague in terms of social and political expressions.

Political practice in France has faced a long resistance because of race and ethnicity. Various definitions related to race are used to explain historical background in France, even though they are not clear. Theorists argue by questioning about racial differences over the centuries from "objectivity" of racial inequalities to cultural hierarchies. In the 19th century, Todor (1998)'s study on "human diversity" in France illustrates that blood and color were important racial issues, and notes that there was a lack of clarity because "race" was often used interchangeably with "country".

de Gobineau (1915) describes in Inequality of Races the basis of classification using law specifying "race", most of which were related to skin colors "white and black" which is a sociological issue concerning "race" and "ethnicity" in addition to language. Similarly, populations in colonial Algeria were classified according to their regional characteristics, language, and taxation. In spite of political conflicts and rational theories that must be learned and understood, especially about differences that are used to confirm groups of people with differences, importance was given to coexistence among differences. They place emphasis on being responsible for their own duties and obligations but at the same time they compete in producing resources, and take politics to the competition field. For this, the self must be identified by different leaders in order to exclude other groups from being representatives for setting the characteristics of legal, cultural, and social differences.

Ethnic otherness is also found in the article The Others Within by Winichakul (2003), which shows the complexity in the construction of Others in the Thai social context. The article examines the history of written work concerning ethnography in Thailand and found that most written work related to ethnography was produced by Siamese elites. The construction of Siam was based on ethno-spatial classification not the simple contradictory pair they-we classification, that is, hierarchical relationships between groups of people were considered and Siamese elites considered the West a representation of civilization that Siam was to take as a role model. However, when looking back at peoples living in Siam, it was found that the ruling class made them the others. For example, peoples were categorized into "bush people and villagers", which Winichakul (2003) found that the categorization consisting of Westerners, bush people, and rural people, was a result of the discourse of civilization. The discourse took place under Siamese elites' resistance and adaptation against colonialism, and 
the effort in constructing a new type of state with certain boundaries. In other words, the demographic categorization in Siam was performed at the level of signifying meaning. Bush people signifies being backward, uncivilized, with improper manners, and they were constructed to be the opposite. When comparing with civilized Westerners, Siamese elites constructed a signifying meaning to distinguish rural people from bush people but not that bush people were "not Thai". Siamese elites saw that rural peoples consisting of varieties of ethnics could become civilized by including them under the rule of the state, and changing their lifestyle to meet the needs of constructing the nation making an effort in imitating Western civilization. Therefore, Siamese elites placed rural people in a lower position and considered them as being obedient to the state authority. Demographic categorization in Siam to make some groups the otherness is a method to raise or upgrade Siamese elites or to arrange subject positions in the changing cosmology (Winichakul, 2003, pp. 90-94).

Another study that focuses on the construction of ethnic otherness is Sakai: The otherness construction in the context of the development of Thai State by Chusawat (2013), which reflects that development of the Thai state affected Sakai's way of life and made the others. Their simple way of life in the forest was affected by the Thai state in its development making Sakai the other within, and it is ambivalence of otherness.

\subsection{The Construction of Otherness in the Three Southern Border Provinces of Thailand}

Winichakul (1987) indicates that in the construction process of "geographical identification", it is necessary to consider the process constructing cultural identification. Appending the surrounding areas to be parts of the Siamese Kingdom did not mean accepting "groups of peoples" in the areas to be parts of the "historical, social, and cultural identification" of "Siamese" or "Thais" (Wungeao, 2007). The important issue is how the Thai state with its center in Bangkok looks at these groups of peoples who are different in races and cultures, and how the Thai state manages them to live on the same land. The overall picture is that the state lacks trust in these peoples suspicious of the relations that the groups have with the neighboring countries. However, this concern and the effort in integrating all peoples to be one, with the central part or Bangkok as the model, has been passed on to the government as a way of solving problems in the three Southern border provinces where people are still suspicious about differences, and do not accept the history written by others. Kasetsiri (2000) explains that in the effort by the Thai state in integrating the peoples to be one, it is noticeable that the Thai history did not mention relations with any groups of diversified races and cultures living in the borderlands of Siam. However, among the mechanisms, an important one found was the change of the country's name from "Siam" to "Thailand" when Field Marshal P. Phibunsongkhram was Prime Minister (Wungaeo, 2007).

The process of construction a nation state has constructed otherness to groups of people of difference races who live in the borderlands of the country. It is as if they are pushed to be social and cultural others from the beginning of the process. They were not accepted to be part of the Thai identity or as part of the Thai history and culture in which Thais and the Thai race are the core or ideology, and being Thai with the oneness characteristics (Wungaeo, 2007).

Wittayapak (2003) states that "The process of the construction of the Thai nation state and the process of Thai-ization under the concept of exclusion and nationalism has resulted in Thais who are the majority of the country, and the non-Thais who are the minority becoming "other within" in Thai society.

Similarly, the situation during the cold war period, there was security policy due to a lack of trust towards groups with different cultures and minorities. At the same time, there was policy of assimilation meaning that these groups have to do the same as others who are the majority in the country. Nevertheless, this policy of "doing the same" as others in turns has generated suspicions and a lack of trust towards the state. When the minorities are made the "other within", and feel that they are deprived and oppressed, as a result, their frustration and resentfulness increase to an extent that causes security problems (Wungaeo, 2007).

The construction of otherness in the three Southern border provinces through the mechanism of nationalism is reflected in a study by Chanchaemchoi (2009) that during the transition from absolute monarchy to the government under Field Marshall P. Phibunsongkhram, state convention policy was emphasized, and King Rama VI's administrative policy was abolished. Twelve state conventions were issued such as the announcement on Buddhism as the national religion. Several measures were implemented on Muslims with some conflicts with Islamic principles such as forcing Muslims to pay respect to a Buddha image, and above all, was the abolishment of Islamic law and judges for Islamic law, and Muslims had to go to the Thai Court instead. As a result, there was a protest that was developed to the Southern separatism. Haji Sulong Tohmeena, former Chairman of Pattani Islamic Committee, who was highly respected by locals, demanded the Thai government that agreed to six rules except one about the court. Nevertheless, in the meantime, there was a coup d'état led by Field Marshall Phin 
Choohavan, and Haji Sulong and his followers were severely suppressed. Haji Sulong and four of his followers were arrested in 1948 and were released in 1952.

In addition, it was found that during the administration of the government led by Field Marshal Sarit Thanarat, approximately 300,000 Thai Buddhists were migrated from the Northeastern part of the country to live in Satun, Yala, and Narathiwat according to the Self-settlement Community project. That resulted in Thai Muslims' resentfulness believing that the government was implementing policy of assimilation on Muslims, and that the government used force to suppress insurgents leading to some Muslims joining the Communist Party, and it has been a chronic problem until today (Chanchaemchoi, 2009; Kornmai, 2010).

According to Bamrungsuk (2004) and Kornmai (2010), there are several causes of the chronic unrest situation in the Southern border provinces as follows. 1) Social and cultural differences-In the past, the area where the Southern border provinces are situated used to be a state called "Pattani State", which was economically, and culturally stable, but later it was appended to the nation state of Siam. This basically caused locals to feel the differences that are not integrated with the nation state and such feeling has developed over time. 2) The traditional policy of the Thai state-Generally, when a nation state emerges, it appends nearby territories as parts of the state. However, not only the territorial dimension is appended to the new state but also differences in race, religion, language and culture. Thus, they make the new state diversified with ethnicity inside rather than being a single-race state. Therefore, a modern nation state has cultural diversity inside it, and such diversity originates a concept of national building with an emphasis on assimilation. However, if such a concept is applied to an extreme, it can lead to "creolization" rather than "acculturation" and usually causes the target groups to resist in one way or another. 3) The problem in forming strategies for the Southern part-Strategies are usually designated only in the old style of security framework. As a result, in addition to destroying the political foundation, it causes "united front" in the opposite direction that drive people in the area away from the state, and might finally refuse the state.

The Southern border area in the past was an area remote from development and adjacent to Melayu land. Communities emerged when people on the Siam land and Melayu land settled in the area that was abundant with natural resources. People in the Southern borderland of Siam and people in the Northern Area of Malaysia had close relationships and many with kinship relationships. They have exchanged, traded, and carried out trading for such a long time. After the two states began to establish their authority politically and administratively, the borderlands on both sides became more important legally and politically. Crossing the borders back and forth freely became illegal as the areas became authority areas for checking and controlling. The dynamic changes have brought about myths on otherness in terms of race, religion, language, and culture (Boonprakarn, 2008).

Presently, the area of the three Southern border provinces is perceived by outsiders as conflict and unrest area, especially from 2004, when 20 schools in Narathiwat Province were burned down, over 400 rifles were robbed from an army barracks of the 4th Battalion for Development, Khai Krom Luang Naradhiwas Rajanagarindhra Military Area, Ban Pileng, Cho Airong District, Narathiwat Province. The incidents made the situation worse and violence has increased continuously until six schools in Thung Yang Daeng District, and Mayo District in Pattani Province were burned down on October 12, 2014 (Burning to Embarrass Big Tu: Southern Insurgents Burned Down Six Schools in Pattani, 2014). Students and teachers demonstrated to protest the violence against the schools which made them the others in the three Southern border provinces. The unrest situation has become an image for the three Southern border provinces. In addition, it was found that there is separation between groups of people with different religions into "them" and "us" as evidenced by the news about attacks against groups of Thai Buddhist teachers going to work at school, and Buddhist monks walking to accept morning offerings of alms. Therefore, it can be seen that otherness has been constructed in the three Southern border provinces through the unrest situation (Tahey, 2013).

A study by Tahey and Boonprakan (2013) about the change of the road surface to military checkpoints in the three Southern border provinces reflects soldiers occupying the road surface by setting up military checkpoints even though checkpoints on the road are under the police responsibility. The reason could be because the roads linking the three Southern border provinces are considered sensitive and vulnerable to stability of state authority. Thus, it is necessary to have measures to take back the areas to the state authority in order to maintain sovereignty according to the form of being a nation state. The areas selected to set up checkpoints are as follows. 1) Red areas designated by the state intelligence agency taking into consideration reports on violent movements in the areas; 2) Important intersections; 3) The area in front of government organizations, temples, schools, and electricity stations emphasizing on protecting the places; and 4) Emergency checkpoints or mobile checkpoints, which can be seen after a violent incident taking place. These emergency checkpoints consist of a number of soldiers, easily movable barricades such as traffic cones. Soldiers watch the entrances and exits around the areas 
of the incidents or areas that have been assigned according to reports and the operations in these areas are usually temporary. Military checkpoints were set up after the incident of gunmen raided and army barracks and took with them a few hundreds of rifles in 2004. The military began the role of road management by setting up tents on the traffic surface with iron barricades and traffic calming devices to slow down vehicles on important roads and intersections in the area to limit the freedom of causal factors of violence. Soldiers also play an important role in some areas where there are supporting factors for setting up military checkpoints such as police booths in town, and village defense volunteer checkpoints. This changes the status of the area to be a military area with military checkpoints equipped with devices for preventing sabotages such as closed circuit cameras and high towers but these are made flexible and movable to accommodate needs for the use of road surface on other occasions (Chawana, 2007).

Tahey (2013) found that the practice of otherness at military checkpoints towards commuters in the unrest situation has many meanings as follows. 1) It constructs otherness towards the role of the police by reducing traffic rules in the area such as not allowing motorcyclists to wear helmets in order to have closed circuit cameras record passer-bys with their faces visible. 2) It constructs otherness towards commuters by repressing their rights as citizens because of closures or changes of some traffic lanes, and they are searched at different levels from being shone in the car with a flashlight to having their personal data on the ID card recorded. 3. It constructs otherness to the community where the checkpoint is set up because the community is being watched in terms of security. 4) It constructs otherness towards officers who have to follow vague policy, and to risk being attacked by unknown parties, and towards officers from other places who have to work in unfamiliar environments.

On the contrary, a study by Baka, Laeheem, and Abru (2006) found that in people's point of view, government officials have created otherness for them, and that it is the cause of the unrest situation in the three Southern border provinces. They felt they did not receive justice, that is, government officials suppressed people violently with discrimination and oppression, and innocent people were arrested. As a result, people were suspicious of government officials. Other causes included culture was mixed up by replacing Thai with the Malay dialect; government officials disliked Muslims; Islam was damaged; there was insincerity towards teaching and learning Islam; Muslims were not accepted as Thais; local culture was not accepted; and religious dress codes were prevented. Furthermore, it was found that the causes of the unrest situation included propaganda to encourage people to fight for their religion, which was thought to be one of the causes by most people, followed by people's dissatisfaction with government policy, personal conflict resulting drug-related problems, insurgency, and influential individuals. Besides, it was found that bombs were planted to destroy bridges, railroads, and government offices to retaliate the state's injustice and oppression. Military and police officers were killed because they despised, bullied, and intimidate Muslims. Innocent people were killed because insurgents wanted to put pressure on the state and to challenge the state. Some people thought that schools were burned down and teachers were killed because they damaged Muslims' traditions and culture. In the study, solutions to the unrest situation were suggested by people. They include the state should manage government officials who do not understand culture and thus, are bias towards Muslims. As many locals as possible should be recruited as government officials. Good attitudes towards Pondok and Toh Khru are needed. Influential individuals in the area should be seriously and completely eliminated. Government officials who have violated disciplines should not be sent to work in the area as punishment. Violence should not be used in solving the problem. Lastly, the state should make the three Southern border provinces into a Special Administrative Region.

Yaena (2007) found in her study that the media describe the causes of the problem from the state's viewpoint and give importance to the government's discourse that places emphasis on otherness that is part of the primary cause of the unrest situation. This is because media give importance to presenting news about the problem and situation in the Southern border provinces, state policy and solutions to the problems, daily killing, bomb blasts, and arrests of insurgents by describing the incidents with emphasis on using language that can attract readers' interest, and on sources of news that are mainly either politicians or state officials. This corresponds with a study by Thapthiang (2007) who considers that having been aware and having received news from the media about the unrest situation in the three Southern border provinces continuously for three years can affect perception and cause misunderstanding as well as negative attitudes towards Islam and Muslims. As a result, it contributes to building otherness because people in the three Southern border provinces feel that, so far media have not truly been media for public interest. Not only that they have not been useful for social integration and unity but also not given importance and respect to cultural differences. Media should present true and correct information that can eliminate misunderstanding. Similarly, there are mechanisms the state has created to prevent harmful incidents such as setting up military checkpoints, soldiers patrolling different areas, carrying rifles to protect 
Buddhist monks walking to accept morning alms, blocking some routes in the morning and late afternoon when teachers going back home from school, etc. The state considers these as preventive measures for teachers and monks' security. Mass media that have presented news and information based on data from the state, and that have not given importance to cultural differences for so many years are also a cause of otherness.

However, these measures intensify the separation of "them" and "us" instead of reducing it. If the state makes efforts in understanding cultural diversity, not only understanding other cultures but also linking it to the conditions of the changing authority relationships, the state can probably reduce otherness to a lower degree.

\section{Conclusion}

Otherness is an invention constructed by society under authority relationships to exclude and push away people who are different from us to a lower social position in order to establish greatness and empower our own group. Separating them from us among different ethnic groups, setting stereotypes for minorities saying that they are underdeveloped, backward, uncivilized, or drug traffickers are all otherness constructed by society. Nevertheless, in areas with ethnic diversity, especially the borderland areas of the country or even the area of the three Southern border provinces of Thailand, if the state makes efforts to understand cultural diversity, peoples will be able to live together peacefully and happily.

\section{Acknowledgements}

We are grateful to the Faculty of Liberal Arts, Prince of Songkla University Fund for support for this project.

\section{References}

Bader, V. (2005). Dutch Nightmare? The End of Multiculturalism. Canadian Diversity, 4(1), 9-12.

Baka, D., Laeheem, K., \& Abru, A. (2006). The Attitudes of the People toward Unpeace in the Three Southern Border Provinces of Thailand. Pattani: Islam Studies College, Prince of Songkla University.

Bamrungsuk, S. (2004). The Southern Crisis: Fight with Strategies and Wisdom. Bangkok: Animate Group.

Baudrillard, J., \& Guillaume, M. M. (1994). Figures d'Altérité. Paris: Descartes.

Becker, H. (1963). Outsiders: A Study of the Sociology of Deviance. New York: Free Press.

Bhabha, H. (1994). The Other Question, In Location of Culture. London: Routledge.

Boonprakarn, K. (2008). Muslim Traders across the Border: Their Every Life Practices in Padang Besar, Thailand-Malaysia Borderlands. Doctoral dissertation in Tai Studies, Mahasarakham University, Mahasarakham.

Burning to Embarrass Big Tu: Southern Insurgents Burned Down Six Schools in Pattani. (2014, October 13). Thai Post., p. 1.

Chanchaemchoi, K. (2009). Concept and Policy on Southern Border Provinces Peace-Building (Master's thesis in Political Science). Ramkhamhaeng University, Bangkok.

Charoensin-o-larn, C. (1999). Development Discourse (2nd ed). Bangkok: Wiphasa.

Chawana, S. (2007). The Military and Solving the Problem of the Unrest Situation in the Three Southern Border Provinces (Master's thesis in Political Science). Thammasat University, Bangkok.

Choosawat, S. (2013). "Sakai" and the "Otherness" in the Context of Development of the Thai State (Master's thesis in Human and Social Development). Prince of Songkla University, Songkhla.

Cuff, E. C., Sharrock, W. W., \& Francis, D. W. (1990). Perspectives in Sociology (3rd ed.). London: Boston.

De Gobineau, A. (1915). The Inequality of the Human Races. Translated by Adrian Collins. William Heinemann.

Fabian, J. (1991). Time and the Other. New York: Columbia University Press.

Foucault, M. (1965). Madness and Civilization. New York: Random House.

Foucault, M. (1966). The Order of Things: Archaeology of Human Sciences. London: Tavistock.

Fueangfusakun, A. (2003). Identity: Review of Theories and Conceptual Frameworks. Bangkok: National Research Council on Sociology, Office of National Council of Thailand.

Gans, H. (1979). Symbolic Ethnicity: The Future of Ethnic Groups and Cultures in America. Ethnic and Racial Studies, 2(1), 1-21. http://dx.doi.org/10.1080/01419870.1979.9993248

Hall, S. (1996). The West and the Rest: Discourse and power. In S. Hall, D. Held, D. Hubert, \& K. Thompson (Eds.), Modernity: An introduction to modern societies. Malden, MA: Blackwell. 
Huntington, S. P. (2004). Who Are We? The Challenges to America's National Identity. NY: Simon \& Schuster.

Huspek, M. (1977). Oppositional Discourses and Democracies. New York: Routledge.

Kasetsiri, C. (2000). Thai Military and Politics. Bangkok: Fa Diew Kan.

Kastoryano, R. (2002). Codes of Otherness. Social Research, 77(1), 79-100.

Kornmai, T. (2013). Strategic Management of the Military in the Southern Border Provinces (Doctoral dissertation). Ramkhamhaeng University, Bangkok.

Lamont, M., \& Fournier, M. (Eds.). (1992). Cultivating Symbolic Boundaries and the Making of Inequality. Chicago: University of Chicago Press.

Luttwak, E. (1979). Coup d'état: A Practical Handbook. Cambridge, Massachusetts: Harvard University Press.

Plumwood, V. (1997). Prospecting for Ecological Gold Amongst the Platonic Forms: A Response to Timothy Mahoney. Ethic and Environment, 149-168.

Simmel, G. (1971). "The Stranger." Georg Simmel on Individuality and Social Forms. University of Chicago P.

Simon, P. (1999, March-April). Sciences Sociales et Racismes: Où Sont les Docteurs Folamour? Mouvements, 3, $111-115$.

Soontravaravit, N. (2013). The Constructed Meanings and Identities of "Gays" in Real Space and Cyber Space (Master's thesis in Human and Social Development). Prince of Songkla University. Songkhla.

Tahay, S. (2013). Military Checkpoints: Occupancy of Spaces and Construction of Otherness for Commuters in the Three Southern Border Provinces (Master's thesis, Prince of Songkla University. Songkhla).

Tahey, S., \& Boonprakan, K. (2013). Changing Road Surfaces to the Military Checkpoints in the Three Southern Border Provinces. In the 5th a National Graduate Research Conference, on August 29, 2013 at the Grand Conference Room, Floor 2, Pho Khun Ramkhamhaeng the Great Conference Building, and Srichum Building Room 502, Ramkhamhaeng University, Bangkok (pp. 25-35). Ramkhamhaeng University.

Thapthiang, N. (2007). Effects of Mass Media: Attitudes of People in the Three Southernmost Province towards News Coverage on Violent Crises. Pattani: Prince of Songkla University.

Todor, T. (1988). Nous et les Autres. La Pensee Politique Francaise sur la Diversite Humaine. Paris: Ed. Seuil.

Winichakul, T. (2000). The Others within: Travel and Ethno-spatial Differentiation of Siamese Subjects 1885-1910. In A. Turton (Ed.), Civility and Savagery: Social Identity in Tai State (pp. 38-59). Richard, Surrey: Curzon Press.

Winichakul, T. (2003, January-April). The Others within. Fa Diew Kan, 1(1), 90-94.

Winichakun, T. (1987). History of Self Construction. In S. Chantornvong, \& C. Sata-anan (Eds.), Living in Thailand: Anthology of Social and Political Articles Honoring Prof. Saneh Chamarik on the Occasion of His 60th Birthday (pp. 124-180). Bangkok: Thammasat University Press.

Winichakun, T. (2001). Postmodern Historical Study. In K. La-ongsri, \& T. Apornsuwan (Eds.), Forgetting Ancestors is Burning Your Own Land. Bangkok: Matichon.

Wittayapak, C. (1998). Social Sciences and Marginal Studies. Journal of Social Science, Chiang Mai University, $11(1)$.

Wungaeo, S. (2000). Globalization and the Subject Matter of Sociology. Social Sciences, 12(2), 15-42.

Wungaeo, S. (2003). Marginalization. Bangkok: Office of National Research Council of Thailand.

Wungaeo, S. (Ed.). (2007). Extinguishing the Southern Fire. Bangkok: Chulalongkorn University.

Wungaeo, S. (Ed.). (2008). Origin of the Southern Fire (2nd ed.). Bangkok: Chulalongkorn University.

Yaena, S. (2007). Representation, Ideology and Discourse of News Media on the Southern Situations of Thailand. Pattani: Faculty of Communication Sciences, Prince of Songkla University.

\section{Copyrights}

Copyright for this article is retained by the author(s), with first publication rights granted to the journal.

This is an open-access article distributed under the terms and conditions of the Creative Commons Attribution license (http://creativecommons.org/licenses/by/3.0/). 